\title{
The Oenococcus oeni genome: physical and genetic mapping of strain GM and comparison with the genome of a 'divergent' strain, PSU-1
}

\author{
Líbia Zé-Zé ${ }^{1,2}$, Rogério Tenreiro ${ }^{1,2}$ and Helena Paveia ${ }^{1,2}$ \\ Author for correspondence: Rogério Tenreiro. Tel: +351 21 7500000. Fax: +351217500048. \\ e-mail: rpat@fc.ul.pt
}

1 Departamento de Biologia Vegetal, FCUL, Campo Grande, 1749-016 Lisboa, Portugal

2 Centro de Genética e Biologia Molecular, UL, 1749-016 Lisboa, Portugal
The physical and genetic maps of the Oenococcus oeni strains GM and PSU-1, which represent two genomic divergent groups on the basis of macrorestriction and ribotyping analysis, were compared. To achieve this comparison, the GM maps were constructed and the PSU-1 maps, already established, were improved. All the recognition sites of the restriction enzymes Ascl, I-Ceul, Fsel, Notl and Sfil were located in both chromosomes and the position of $\mathbf{2 6}$ genetic markers, including two rrn operons and 14 new putative oenococcal genes, were allocated to the restriction fragments generated by the five enzymes. The comparative analysis of $O$. oeni GM and PSU-1 genomes revealed extensive conservation of loci order. As for the differences encountered in the locations of restriction sites, they seem to be a reflection of the differences in restriction fragment sizes, explainable by insertion/deletion events and point mutations. No evidence for major genomic rearrangements was found. The genomic conservation between the two strains is in agreement and suggests homogeneity within the species, which was not unexpected in view of the restricted ecological niche of 0 . oeni. Further comparisons of physical maps, both of $O$. oeni strains and related species, will certainly help to assess whether 0 . oeni is really an homogeneous species and physical mapping is suitable for taxonomic purposes, both at the supra- and intraspecific levels.

Keywords: Oenococcus oeni, genomic maps, comparative genome analysis

\section{INTRODUCTION}

The genus Oenococcus, first described by Dicks et al. (1995), contains a sole species, Oenococcus oeni, formerly known as Leuconostoc oenos. O. oeni has a restricted ecological niche (wine and related habitats), a peculiar acidophilic nature and viability at high ethanol levels (Garvie, 1986) and, although its dissimilarity to other leuconostocs is fully accepted, there is some controversy regarding both the evolution rate of the species (Martínez-Murcia et al., 1993; Morse et al., 1996) and its diversity (Dicks et al., 1990; Zavaleta et al., 1996). Based on metabolic/physiological criteria, splitting of $\mathrm{O}$. oeni into two species was once proposed (Peynaud \& Domercq, 1968), but the levels of DNADNA homology $(73-110 \%$; Dicks et al., 1990) are in agreement with the genomic concept of bacterial species. More recently, the characterization of 30 strains of $O$. oeni of different origins on the basis of macrorestriction profiles and ribotyping, clustered them in two groups and led to the suggestion that the species might be divided into two subspecies (Tenreiro et al., 1994 and unpublished results).

To determine the validity of this assumption and gain insight into the genomic variability within $O$. oeni, we report here the comparison of the genomes of strains GM and PSU-1. These strains were chosen since, besides being representative of the above-mentioned clusters, they are used as starters for induction of the malolactic fermentation of wines and are therefore industrially important. To achieve this comparison, we constructed a physical and genetic map of the O. oeni GM chromosome and improved the existing physical and genetic maps of O. oeni PSU-1 (Zé-Zé et al., 1998).

\section{METHODS}

Bacterial strains and growth conditions. Growth conditions for O. oeni strains GM (Microlife Techniques) and PSU-1 (R. Kunkee, University of California at Davis, USA) were de- 
Table 1. PCR conditions used to amplify gene sequences used as probes

\begin{tabular}{|c|c|c|c|c|c|}
\hline Gene & Function & Primer pair $\left(5^{\prime}-3^{\prime}\right)^{*}$ & PCR cycles $\dagger$ & $\begin{array}{l}\text { Approx. } \\
\text { fragment size } \\
\qquad(\mathrm{kb})\end{array}$ & $\begin{array}{l}\text { Reference for } \\
\text { primers }\end{array}$ \\
\hline $\operatorname{ccp} A$ & $\begin{array}{l}\text { Catabolite } \\
\text { control } \\
\text { protein A }\end{array}$ & $\begin{array}{l}\text { CGGAATTCATHTAYGAYGAYGTNGC } \\
\text { and } \\
\text { CGGGATCCACNGCNCCDATRTCRTA }\end{array}$ & $\begin{array}{l}\text { ID }+35 \text { cycles: } \\
94^{\circ} \mathrm{C} 1 \mathrm{~min}, \\
44^{\circ} \mathrm{C} 2 \mathrm{~min}, \\
72^{\circ} \mathrm{C} 1 \mathrm{~min}+\mathrm{FE}\end{array}$ & $0 \cdot 4$ & This study $\neq$ \\
\hline gyrB & $\begin{array}{l}\text { DNA gyrase } \\
\text { subunit B }\end{array}$ & $\begin{array}{l}\text { GAAGTCATCATGACCGTTCTGCAY } \\
\text { GCNGGNGGNAARTTYGA and } \\
\text { AGCAGGGTACGGATGTGCGAGCCR } \\
\text { TCNACRTCNGCRTCNGTCAT }\end{array}$ & $\begin{array}{l}\text { ID }+30 \text { cycles: } \\
94^{\circ} \mathrm{C} 1 \mathrm{~min}, \\
60^{\circ} \mathrm{C} 2 \mathrm{~min}, \\
72^{\circ} \mathrm{C} 2 \mathrm{~min}+\mathrm{FE}\end{array}$ & $1 \cdot 4$ & $\begin{array}{l}\text { Yamamoto \& } \\
\text { Harayama (1995) }\end{array}$ \\
\hline rpoC & $\begin{array}{l}\beta^{\prime} \text {-subunit } \\
\text { DNA } \\
\text { polymerase }\end{array}$ & $\begin{array}{l}\text { TGYTCWTGYGGWAARTAYAA and } \\
\text { CATWACYTCWACRTGYTTRTC }\end{array}$ & $\begin{array}{l}\text { ID }+30 \text { cycles: } \\
94^{\circ} \mathrm{C} 1 \mathrm{~min}, \\
48^{\circ} \mathrm{C} 1 \mathrm{~min}, \\
72^{\circ} \mathrm{C} 2 \mathrm{~min}+\mathrm{FE}\end{array}$ & $1 \cdot 1$ & $\begin{array}{l}\text { Morse et al. } \\
\text { (1996) }\end{array}$ \\
\hline $\sec A$ & SecA ATPase & $\begin{array}{l}\text { CGGAATTCATHGAYGARGCNMGNAC } \\
\text { and CAGGATCCCKNCCNGCCATRT } \\
\text { TNGT }\end{array}$ & $\begin{array}{l}\text { ID }+35 \text { cycles: } \\
94^{\circ} \mathrm{C} 1 \mathrm{~min}, \\
44^{\circ} \mathrm{C} 2 \mathrm{~min}, \\
72^{\circ} \mathrm{C} 2 \mathrm{~min}+\mathrm{FE}\end{array}$ & $0 \cdot 9$ & This study $\neq$ \\
\hline hexB & $\begin{array}{l}\text { Mismatch } \\
\text { repair }\end{array}$ & $\begin{array}{l}\text { CTGTCAGTAACTTTGGAG and } \\
\text { AAATGGACAATCGTTGGC }\end{array}$ & $\begin{array}{l}\text { ID }+30 \text { cycles: } \\
94^{\circ} \mathrm{C} 1 \mathrm{~min}, \\
56^{\circ} \mathrm{C} 2 \mathrm{~min}, \\
72^{\circ} \mathrm{C} 1 \mathrm{~min}+\mathrm{FE}\end{array}$ & $0 \cdot 6$ & $\begin{array}{l}\text { Duwat et al. } \\
\text { (1997) }\end{array}$ \\
\hline
\end{tabular}

*Abbreviations: $\mathrm{B}=\mathrm{C}, \mathrm{G}$ or $\mathrm{T} ; \mathrm{D}=\mathrm{A}, \mathrm{G}$ or $\mathrm{T} ; \mathrm{H}=\mathrm{A}, \mathrm{C}$ or $\mathrm{T} ; \mathrm{M}=\mathrm{A}$ or $\mathrm{C} ; \mathrm{N}=\mathrm{A}, \mathrm{C}, \mathrm{G}$ or $\mathrm{T} ; \mathrm{R}=\mathrm{A}$ or $\mathrm{G} ; \mathrm{S}=\mathrm{C}$ or $\mathrm{G} ; \mathrm{Y}=\mathrm{C}$ or $\mathrm{T}$. Underlined sequences represent non-complementary restriction sites for cloning strategies.

†ID, Initial denaturation: $94{ }^{\circ} \mathrm{C} 5 \mathrm{~min}$; FE, final extension $72{ }^{\circ} \mathrm{C} 5 \mathrm{~min}$.

‡Supplied by M. A. Santos (DBV, FCUL, Lisbon).

scribed by Tenreiro et al. (1993). Escherichia coli JM109 and $\mathrm{XL}-1$ Blue (Stratagene) were grown at $37^{\circ} \mathrm{C}$ in $\mathrm{LB}$ broth, supplemented with $100 \mu \mathrm{g}$ ampicillin $\mathrm{ml}^{-1}$ when required.

Isolation and restriction of chromosomal DNA, and DNA fragment nomenclature. Intact genomic DNA was prepared in agarose plugs and single or double digested with the restriction enzymes AscI, NotI, FseI and SfiI as described previously (Tenreiro et al., 1994; Zé-Zé et al., 1998). I-CeuI digestion proceeded for $10-12 \mathrm{~h}$ with $0 \cdot 1-0 \cdot 2 \mathrm{U}$ enzyme per agarose plug. All the enzymes were purchased from New England Biolabs.

Restriction fragments produced by digestion with a single enzyme are indicated by the initial letter of the endonuclease. Those obtained by double digestion were designated using the letters of the first and second digestions joined by a hyphen. All fragments were numbered in size order, from the largest to the smallest. Co-migrating fragments were numbered with sequential numbers.

PFGE. PFGE and two-dimensional PFGE were carried out in the Gene Navigator system (Pharmacia) with contourclamped homogeneous field (CHEF) or Geneline (Beckman) with transverse alternating field (TAFE), as previously described (Zé-Zé et al., 1998). The mean size of each fragment was estimated from several gels by linear interpolation with two flanking size standards (Heath et al., 1992) using KODAK 1D 2.0 software (Kodak). Saccharomyces cerevisiae chromosomes (Bio-Rad), lambda DNA, mid-range and low-range PFG ladders (New England Biolabs) were used as size markers.
DNA probes. Preparation of $\left[\alpha-{ }^{32} \mathrm{P}\right] \mathrm{dCTP}$-labelled DNA probes and Southern hybridization conditions were as previously described (Zé-Zé et al., 1998).

The DNA sequences used as probes in this study are reported below and listed in Table 3 . The restriction fragments generated from O. oeni PSU-1 and GM chromosomes by the endonucleases AscI, FseI, NotI and SfI were described previously (Zé-Zé et al., 1998).

Gene sequences obtained by PCR, and primers and amplification conditions are listed in Table 1. PCR was performed in a Robocycler (Stratagene) and the reaction mixtures contained $50 \mathrm{pmol}$ each primer (purchased from Gibco-BRL), $250 \mu \mathrm{M}$ each dNTP, $1.5 \mathrm{mM} \mathrm{MgCl}_{2}$ and 2.0 U Taq DNA polymerase, in the supplied buffer (Gibco-BRL). Reactions were performed with approximately $200 \mathrm{ng}$ O. oeni PSU-1 genomic DNA, except for hexB from Lactococcus lactis (cloned in plasmid pDU190-1; Duwat et al., 1997), where $100 \mathrm{ng}$ plasmid was used as template. RAPD 1.2 is a randomly amplified polymorphic DNA fragment of $\sim 1.2 \mathrm{~kb}$ from strain PSU-1.

Most of the plasmids harbouring sequences from PSU-1 have already been described (Zé-Zé et al., 1998). The plasmid pZAR4.7 was constructed by subcloning, in pBluescript KS II (pKS II; Stratagene), a $4.7 \mathrm{~kb}$ EcoRI fragment from a clone of a genomic library of O. oeni PSU-1 in lambda DASH II (Stratagene) which hybridized with araA from Bacillus subtilis (pSNL4, Sá-Nogueira et al., 1997). pMIR0.5 was constructed by subcloning in pKS II a $0.5 \mathrm{~kb}$ Pst I fragment from $\mathrm{pLB} 3$ (pMK4 with an insert of a $5 \cdot 1 \mathrm{~kb}$ Sau3AI fragment from strain 


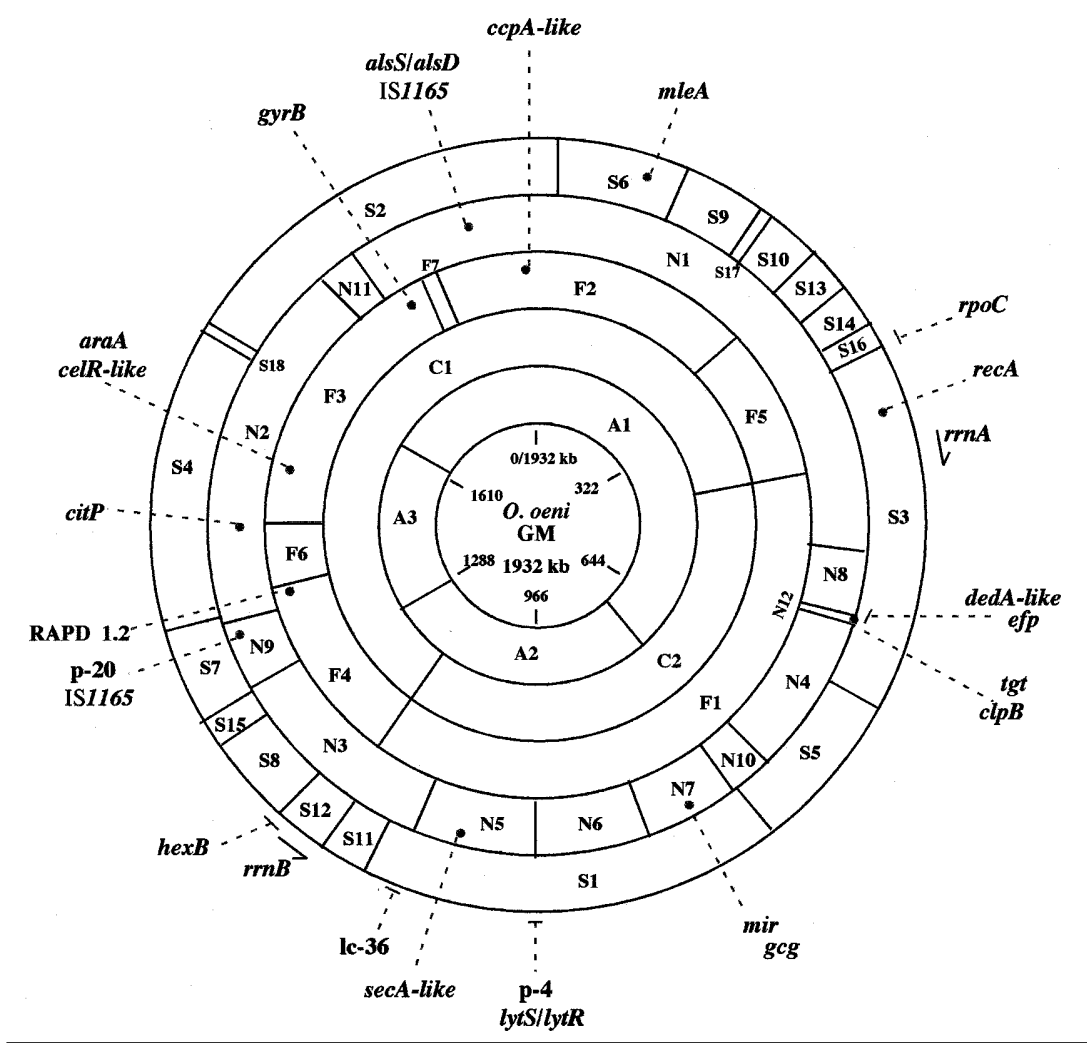

Fig. 1. Physical map of the chromosome of O. oeni GM using the enzymes Ascl, I-Ceul, Fsel, Notl and Sfil. Radiating out from the centre, the five annuli show the restriction sites for the five enzymes, respectively. The locations of the genetic markers are also shown, although the order of markers in a single fragment is arbitrary. Direction of transcription of $r r n$ operons is indicated by arrows. Scale is in $\mathrm{kb}$.

Table 2. Sizes $(\mathrm{kb})$ of restriction fragments obtained by cleavage of the 0 . oeni GM chromosome

\begin{tabular}{|c|c|c|c|c|c|c|c|c|c|c|}
\hline \multirow[t]{2}{*}{ Fragment } & \multicolumn{2}{|c|}{$A s c \mathrm{I}$} & \multicolumn{2}{|c|}{$\mathrm{I}-\mathrm{Ceu} \mathrm{I}$} & \multicolumn{2}{|c|}{ FseI } & \multicolumn{2}{|c|}{ NotI } & \multicolumn{2}{|c|}{ SfiI } \\
\hline & $\begin{array}{c}\text { Observed } \\
\text { size }^{*}\end{array}$ & $\begin{array}{c}\text { Map } \\
\text { size } \dagger\end{array}$ & $\begin{array}{c}\text { Observed } \\
\text { size }^{*}\end{array}$ & $\begin{array}{c}\text { Map } \\
\text { size } \dagger\end{array}$ & $\begin{array}{c}\text { Observed } \\
\text { size }^{*}\end{array}$ & $\begin{array}{c}\text { Map } \\
\text { size } \dagger\end{array}$ & $\begin{array}{c}\text { Observed } \\
\text { size }^{*}\end{array}$ & $\begin{array}{c}\text { Map } \\
\text { size } \dagger\end{array}$ & $\begin{array}{c}\text { Observed } \\
\text { size }^{*}\end{array}$ & $\begin{array}{c}\text { Map } \\
\text { size } \dagger\end{array}$ \\
\hline 1 & 1088 & 1089 & 1195 & 1200 & 746 & 733 & 701 & 696 & 345 & 340 \\
\hline 2 & 521 & 520 & 736 & 732 & 376 & 382 & 344 & 350 & 336 & 330 \\
\hline 3 & 318 & 323 & & & 325 & 330 & 200 & 202 & 294 & 295 \\
\hline 4 & & & & & 233 & 233 & 154 & 154 & 242 & 242 \\
\hline 5 & & & & & 174 & 175 & 128 & 128 & 130 & 137 \\
\hline 6 & & & & & 61 & 61 & 105 & 102 & 111 & 110 \\
\hline 7 & & & & & 16 & 18 & 85 & 83 & 73 & 73 \\
\hline 8 & & & & & & & 63 & 63 & 73 & 72 \\
\hline 9 & & & & & & & 62 & 62 & 65 & 62 \\
\hline 10 & & & & & & & 47 & 46 & 53 & 53 \\
\hline 11 & & & & & & & 38 & 38 & 39 & 39 \\
\hline 12 & & & & & & & 6 & 7 & 39 & 39 \\
\hline 13 & & & & & & & & & 35 & 35 \\
\hline 14 & & & & & & & & & 33 & 35 \\
\hline 15 & & & & & & & & & 25 & 26 \\
\hline 16 & & & & & & & & & 21 & 21 \\
\hline 17 & & & & & & & & & 16 & 16 \\
\hline 18 & & & & & & & & & 7 & 7 \\
\hline Total & 1927 & 1932 & 1931 & 1932 & 1930 & 1932 & 1933 & 1932 & 1934 & 1932 \\
\hline
\end{tabular}

* The observed sizes are mean values, calculated from 3-24 determinations. The maximal deviation in size was estimated to be less than $4.9 \%$.

† The map sizes are theoretical sizes of fragments calculated by placing restriction sites on the map. 
Table 3. DNA sequences used as probes in this study and their location on the O. oeni GM chromosome

${ }^{\mathrm{T}}$, type strain; ND, not determined.

\begin{tabular}{|c|c|c|c|c|c|c|c|c|}
\hline \multirow[t]{2}{*}{ Probe } & \multirow{2}{*}{$\begin{array}{c}\text { Gene } \\
\text { (function/description) }\end{array}$} & \multirow[t]{2}{*}{ Origin } & \multicolumn{5}{|c|}{ Hybridizing fragment(s) } & \multirow[t]{2}{*}{ Reference } \\
\hline & & & $A s c \mathrm{I}$ & $\mathrm{I}-\mathrm{CeuI}$ & FseI & Not $\mathrm{I}$ & SfiI & \\
\hline \multicolumn{9}{|l|}{ Plasmids } \\
\hline $\mathrm{pRT} 1$ & rrs (16S rRNA gene) & O. oeni $\mathrm{L} 217^{\mathrm{T}}$ & $\mathrm{A} 1, \mathrm{~A} 2$ & C1 & $\mathrm{F} 1, \mathrm{~F} 4, \mathrm{~F} 5$ & N1, N3 & S3, S12 & $\begin{array}{l}\text { Zé-Zé et al. } \\
\text { (1998) }\end{array}$ \\
\hline pSNL4 & $\begin{array}{l}\operatorname{ara} A(\mathrm{~L} \text {-arabinose } \\
\text { isomerase) }\end{array}$ & B. subtilis & $\mathrm{A} 3$ & $\mathrm{C} 1$ & F3 & $\mathrm{N} 2$ & ND & $\begin{array}{l}\text { Sá-Nogueira } \\
\text { et al. (1997) }\end{array}$ \\
\hline pZAR4.7 & $\begin{array}{l}\operatorname{araA}(\mathrm{L} \text {-arabinose } \\
\text { isomerase) }\end{array}$ & O. oеni PSU-1 & $\mathrm{A} 3$ & $\mathrm{C} 1$ & $\mathrm{~F} 3$ & $\mathrm{~N} 2$ & $\mathrm{ND}$ & This study \\
\hline pZN11 & 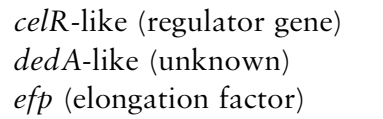 & O. oeni PSU-1 & $\mathrm{A} 1$ & ND & $\mathrm{F} 1$ & N8, N12 & S3 & This study \\
\hline pZN12 & $\begin{array}{l}\text { tgt }(\text { tRNA } \\
\text { ribosyltransferase) }\end{array}$ & O. oеni PSU-1 & $\mathrm{A} 1$ & ND & ND & N12 & S3 & This study \\
\hline $\mathrm{p}-4$ & $\begin{array}{l}\text { lyt } \mathrm{S} / \text { lytR (NotI linking } \\
\text { clone) }\end{array}$ & O. оепi PSU-1 & $\mathrm{A} 2$ & $\mathrm{C} 2$ & ND & N5, N6 & ND & $\begin{array}{l}\text { Zé-Zé et al. } \\
\text { (1998) }\end{array}$ \\
\hline pLB3 & mir (mitC resistance) & O. oeni PSU-1 & A2 & $\mathrm{C} 2$ & ND & N7 & ND & Brito (1996) \\
\hline pMIR0.5 & $g c g$ (GTP binding protein) & O. oeni PSU-1 & $\mathrm{A} 2$ & $\mathrm{C} 2$ & ND & N7 & ND & This study \\
\hline $\mathrm{pJ} 2 \mathrm{C} 3$ & mleA (malolactic enzyme) & O. oeni Lo84.13 & $\mathrm{A} 1$ & $\mathrm{C} 1$ & $\mathrm{~F} 2$ & N1 & S6 & $\begin{array}{l}\text { Labarre et al. } \\
\text { (1996) }\end{array}$ \\
\hline pGID600 & $\begin{array}{l}\text { als } S, \text { alsD ( } \alpha \text {-acetolactate } \\
\text { synthetase and } \\
\text { decarboxylase) }\end{array}$ & O. oеni Lo84.13 & $\mathrm{A} 1$ & $\mathrm{C} 1$ & ND & N1 & S2 & $\begin{array}{l}\text { Garmyn et al. } \\
\text { (1996) }\end{array}$ \\
\hline pDU36-1 & recA (DNA recombination) & $\begin{array}{l}\text { Leuconostoc } \\
\text { mesenteroides }\end{array}$ & A1 & ND & ND & N1 & S3 & $\begin{array}{l}\text { Duwat et al. } \\
\text { (1992) }\end{array}$ \\
\hline pAK6.9 & IS1165 (insertion sequence) & $\begin{array}{l}\text { Leu. } \\
\text { mesenteroides }\end{array}$ & A1, A3 & $\mathrm{C} 1$ & $\mathrm{~F} 2, \mathrm{~F} 4$ & N1, N9 & S2, S7 & $\begin{array}{l}\text { Johansen \& } \\
\text { Kibenich } \\
(1992)\end{array}$ \\
\hline pFS21 & citP (citrate permease) & Lac. lactis & A3 & ND & ND & $\mathrm{N} 2$ & S4 & $\begin{array}{l}\text { Sesma et al. } \\
\text { (1990) }\end{array}$ \\
\hline lc-36 & Not I linking clone & O. oеni PSU-1 & $\mathrm{A} 2$ & $\mathrm{C} 2$ & ND & N3, N5 & S1 & $\begin{array}{l}\text { Zé-Zé et al. } \\
\text { (1998) }\end{array}$ \\
\hline p-20 & Not I linking clone & O. oеni PSU-1 & A3 & ND & ND & N9 & S7 & This study \\
\hline \multicolumn{9}{|c|}{ PCR products } \\
\hline $\operatorname{ccp} A$ & $\begin{array}{l}\text { Catabolite control } \\
\text { protein A }\end{array}$ & O. oеni PSU-1 & ND & ND & ND & N1 & S2 & This study \\
\hline $\operatorname{gyr} B$ & DNA gyrase subunit B & O. оепi PSU-1 & A1 & ND & F3 & N1 & S2 & This study \\
\hline rpo C & $\begin{array}{l}\text { DNA polymerase } \beta^{\prime} \text { - } \\
\text { subunit }\end{array}$ & O. оепi PSU-1 & $\mathrm{A} 1$ & $\mathrm{C} 1$ & F5 & N1 & S3, S16 & This study \\
\hline $\sec A$ & SecA ATPase & O. oеni PSU-1 & A2 & ND & ND & N5 & ND & This study \\
\hline hexB & Mismatch repair & Lac. lactis & A2 & $\mathrm{C} 1$ & ND & N3 & S8, S12 & This study \\
\hline RAPD 1.2 & RAPD fragment & O. oеni PSU-1 & A3 & $\mathrm{C} 1$ & $\mathrm{~F} 4$ & $\mathrm{~N} 2$ & S4 & This study \\
\hline \multicolumn{9}{|c|}{ PSU-1 DNA fragments } \\
\hline $3^{\prime} \mathrm{rrl}$ & $r r l$ (23S rRNA fragment) & O. oеni PSU-1 & $\mathrm{A} 1, \mathrm{~A} 2$ & $\mathrm{C} 2$ & $\mathrm{~F} 1$ & $\mathrm{~N} 1, \mathrm{~N} 3$ & S3, S12 & This study \\
\hline A3 & & O. oeni PSU-1 & A3 & ND & ND & N3, N9 & S4, S7 & This study \\
\hline A4 & & O. oeni PSU-1 & ND & ND & ND & $\mathrm{N} 2$ & $\mathrm{ND}$ & This study \\
\hline F1 & & O. oeni PSU-1 & $\mathrm{A} 1, \mathrm{~A} 2$ & C2 & ND & $\begin{array}{l}\text { N1, N3, } \\
\text { N4, N5, } \\
\text { N6, N7, } \\
\text { N8, N10 }\end{array}$ & $\begin{array}{l}\mathrm{S} 1, \mathrm{~S} 3, \mathrm{~S} 5 \\
\mathrm{~S} 11, \mathrm{~S} 12\end{array}$ & This study \\
\hline F3 & & O. оепi PSU-1 & $\mathrm{A} 2, \mathrm{~A} 3$ & ND & $\mathrm{F} 4, \mathrm{~F} 6$ & $\begin{array}{l}\text { N2, N3, } \\
\text { N9 }\end{array}$ & $\begin{array}{l}\text { S4, S7, S8, } \\
\text { S12, S15 }\end{array}$ & This study \\
\hline
\end{tabular}


Table 3 (cont.)

\begin{tabular}{|c|c|c|c|c|c|c|c|c|}
\hline \multirow[t]{2}{*}{ Probe } & \multirow{2}{*}{$\begin{array}{c}\text { Gene } \\
\text { (function/description) }\end{array}$} & \multirow[t]{2}{*}{ Origin } & \multicolumn{5}{|c|}{ Hybridizing fragment $(s)$} & \multirow[t]{2}{*}{ Reference } \\
\hline & & & $A s c \mathrm{I}$ & $\mathrm{I}-\mathrm{CeuI}$ & FseI & NotI & $S f i \mathrm{I}$ & \\
\hline N1 & & O. oeni PSU-1 & $\mathrm{A} 1, \mathrm{~A} 3$ & ND & ND & $\begin{array}{l}\text { N1, N2, } \\
\text { N11 }\end{array}$ & $\begin{array}{l}\text { S2, S4, S6, } \\
\text { S7/8, S9, } \\
\text { S13/14 }\end{array}$ & This study \\
\hline $\mathrm{N} 2$ & & O. oеni PSU-1 & $\mathrm{A} 2, \mathrm{~A} 3$ & ND & ND & N3, N9 & $\begin{array}{l}\text { S1, S7/8 } \\
\text { S11/12, } \\
\text { S15 }\end{array}$ & This study \\
\hline $\mathrm{N} 2 / 3$ & & O. oеni PSU-1 & ND & ND & ND & $\begin{array}{l}\text { N1, N2, } \\
\text { N3, N9 }\end{array}$ & $\begin{array}{l}\text { S1, S3, S4, } \\
\text { S7/8, } \\
\text { S13/14, } \\
\text { S15, S16 }\end{array}$ & This study \\
\hline $\mathrm{N} 4 / 5$ & & O. oеni PSU-1 & ND & $\mathrm{ND}$ & ND & N4, N5 & S1, S3, S5 & This study \\
\hline N6 & & O. oеni PSU-1 & $\mathrm{A} 2$ & ND & ND & $\mathrm{ND}$ & S1 & This study \\
\hline N11 & & O. oeni PSU-1 & A1 & ND & $\mathrm{F} 1$ & N8, N12 & S3 & This study \\
\hline S1 & & O. oеni PSU-1 & $\mathrm{A} 2$ & ND & ND & $\begin{array}{l}\text { N3, N5, } \\
\text { N6, N7, } \\
\text { N10 }\end{array}$ & S1 & This study \\
\hline S10 & & O. oеni PSU-1 & $\mathrm{ND}$ & ND & ND & N1 & S9 & This study \\
\hline S11/12 & & O. оепі PSU-1 & $\begin{array}{l}\text { A1, A2, } \\
\text { A3 }\end{array}$ & ND & F1, F3 & ND & $\begin{array}{l}\text { S2, S11, } \\
\text { S18 }\end{array}$ & This study \\
\hline S15 & & O. oеni PSU-1 & A1 & ND & ND & N1 & S14, S16 & This study \\
\hline S16 & & O. oеni PSU-1 & $\mathrm{A} 2$ & ND & $\mathrm{ND}$ & N3 & S11/12 & This study \\
\hline \multicolumn{9}{|c|}{ GM DNA fragments } \\
\hline N1 & & O. оепi GM & A1 & ND & ND & ND & $\begin{array}{l}\text { S2, S3, S6, } \\
\text { S9, S10, } \\
\text { S13 S14, } \\
\text { S16 }\end{array}$ & This study \\
\hline N2 & & O. oеni GM & $\mathrm{A} 1, \mathrm{~A} 3$ & ND & ND & N2 & S2, S4, S18 & This study \\
\hline N4 & & O. oeni GM & A1 & $\mathrm{C} 2$ & ND & N4 & S3, S5 & This study \\
\hline $\mathrm{N} 8 / 9$ & & O. oeni GM & $\mathrm{A} 1, \mathrm{~A} 3$ & $\mathrm{C} 1, \mathrm{C} 2$ & ND & N8/9 & $\mathrm{ND}$ & This study \\
\hline N10 & & O. oeni GM & $\mathrm{A} 1, \mathrm{~A} 2$ & ND & ND & N10 & S1, S5 & This study \\
\hline N11 & & O. oeni GM & A1 & ND & ND & N11 & S2 & This study \\
\hline $\mathrm{S} 1 / 2$ & & O. оепi GM & $\mathrm{A} 1, \mathrm{~A} 2$ & ND & ND & $\begin{array}{l}\text { N1, N2, } \\
\text { N3, N5, } \\
\text { N6, N7, } \\
\text { N10, N11 }\end{array}$ & ND & This study \\
\hline S6 & & O. oеni GM & A1 & ND & ND & $\mathrm{N} 1$ & S6 & This study \\
\hline S9 & & O. oeni GM & ND & ND & ND & N1 & S9 & This study \\
\hline S15 & & O. oеni GM & ND & ND & $\mathrm{ND}$ & N3 & S15 & This study \\
\hline S17 & & O. oeni GM & A1 & ND & $\mathrm{F} 2$ & N1 & S17 & This study \\
\hline S18 & & O. oeni GM & $\mathrm{A} 1, \mathrm{~A} 3$ & ND & ND & $\mathrm{N} 2$ & S18 & This study \\
\hline
\end{tabular}

PSU-1 that confers resistance to mitomycin C; Brito, 1996). Plasmids pZN11 and pZN12 were obtained by shotgun cloning of PSU-1 DNA in pKS II, both digested with NotI. Plasmids p-4 and lc-36 contain NotI linking clones of O. oeni PSU-1 in pGEM5Z (Promega) and pKS II, respectively (Zé-Zé et al., 1998). Plasmid p-20 was isolated when screening for PSU-1 NotI linking clones in pGEM5Z vector.

DNA sequencing and analysis. Non-automated DNA sequencing was performed by the dideoxynucleotide triphosphate chain termination method with $\left[\alpha^{35} \mathrm{~S}\right] \mathrm{dATP}$ and Sequenase version 2.0 kit (USB, Amersham) or with $[\gamma$ $\left.{ }^{32} \mathrm{P}\right] \mathrm{dATP}$ by the dsDNA Cycle Sequencing system (Gibco$\mathrm{BRL}$ ). Automated sequencing was purchased from the " 4 base lab' (Reutlingen) which uses the ALF Sequencer (Pharmacia).

DNA sequences were analysed by DNASIs (Hitachi) and, for database searches, the BLAST programs (Altschul et al., 1997) were used on the NCBI Sequence Database (http:// www.ncbi.nlm.nih.gov).

\section{RESULTS}

\section{Physical mapping of the 0 . oeni GM chromosome}

In a previous study, a physical map of the O. oeni PSU1 chromosome was constructed using the enzymes AscI, 


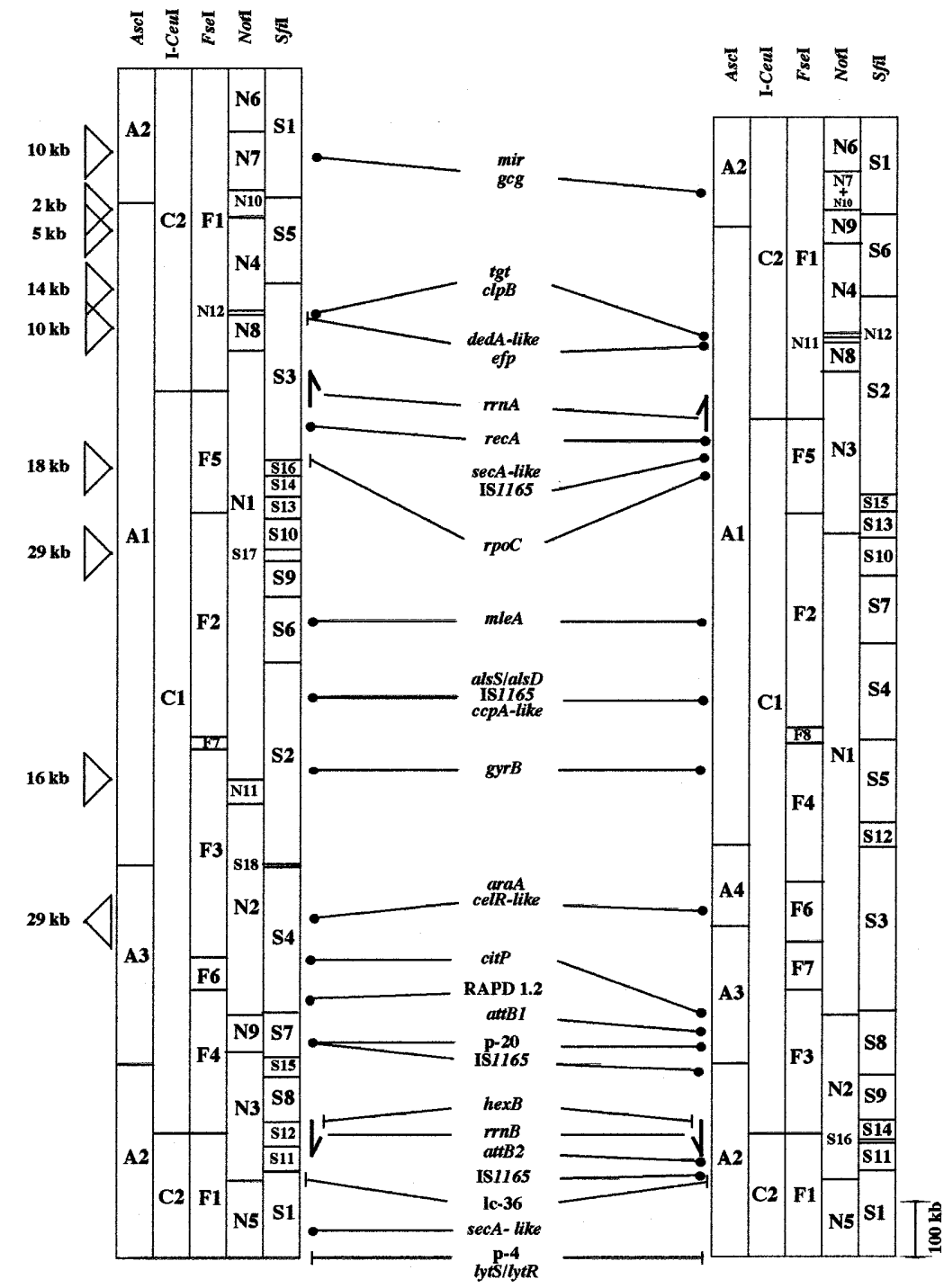

o. oeni GM

O. oeni PSU-1
Fig. 2. Comparison of the physical and genetic maps of $O$. oeni strains GM and PSU1. Restriction sites for Ascl, I-Ceul, Fsel, Notl and Sfil are indicated. The circular genomes are shown linearized from a common Notl site, identified by the linking clone p-4. $D$ represents an insertion and $\triangleleft$ a deletion event in the GM chromosome. $\vdash$ and -1 indicate genetic markers assigned to endonuclease recognition sites.
FseI, NotI and SfiI (Zé-Zé et al., 1998). The same rare cutting endonucleases were employed to construct the GM physical map (Fig. 1) and the intron-encoded endonuclease I-CeuI sites were added to both maps.

I-CeuI cuts the genome of both strains twice, identifying two rrn operons in O. oeni located at the limits of the generated fragments (GM C1, $1200 \mathrm{~kb}$; C2, $732 \mathrm{~kb}$; PSU$1 \mathrm{C} 1,1166 \mathrm{~kb}$; C2, $691 \mathrm{~kb})$. Under different digestion conditions, i.e. more than $0 \cdot 2 \mathrm{U}$ enzyme per agarose plug or longer incubation times, restriction with I-CeuI gave rise either to four reproducible fragments or to degradation of the DNA. As the presence of extra $r r l$ gene sequences could be discarded, taking in account the two precisely located $r r n$ operons on the O. oeni PSU-1 physical map (Zé-Zé et al., 1998) and the hybridization analysis with $r r l$ and $r r s$ probes (data not shown), the four-fragment profiles must be artefacts. Although I$\mathrm{Ceu} \mathrm{I}$ is able to cleave the $\mathrm{rrl}$ sequence in most bacteria and lower eukaryotes, these results suggest that the presence of an $\mathrm{rrn}$ operon based solely on the cleavage by I-CeuI (Liu et al., 1993, 1999; Marshall \& Lemieux, 1992) cannot be taken for granted and must be confirmed by hybridization of I-CeuI profiles with $r r l$ and $r r s$ probes. To our knowledge, reproducible extra cutting sites for I-CeuI were never reported. Nevertheless, the absence of I-CeuI cleavage of the $r r l$ gene due to a single base deletion in the recognition sequence has been described in Mycobacterium tuberculosis (Philipp et al., 1996).

Restriction of the O. oeni GM circular chromosome with AscI, FseI, NotI and SfiI produced 3, 7, 12 and 18 fragments, respectively; their estimated mean sizes are presented in Table 2. All fragments were resolvable under the PFGE conditions used, except for three SfiI bands (S7/S8, S11/S12 and S13/S14) which were assumed to be doublets. The size of the O. oeni GM chromosome was estimated to be $1932 \mathrm{~kb}$.

The establishment of relationships between restriction fragments and the mapping of all 42 restriction sites was 
accomplished by a reasoning similar to the one described for the O. oeni PSU-1 physical map (Zé-Zé et al., 1998).

The experimental strategy involved a combined approach using the analysis of double digestions, twodimensional PFGE and Southern hybridization. Besides the assessment of fragment linkage, cross-hybridization with PSU-1 linking clones and restriction fragments both from GM and PSU-1, as well as the use of probes for genetic markers (plasmid cloned genes and PCR products), were essential to the confirmation of the relative order of restriction sites (see Table 3).

The integration of these data and comparison to the $O$. oeni PSU-1 physical map (Fig. 2) led to the physical map of strain GM presented in Fig. 1.

\section{Assignment of genetic markers to the 0 . oeni GM physical map}

The chromosomal locations of 26 genetic markers, namely 23 gene markers, two linking clones and a PSU1 RAPD fragment, were determined (Fig. 1). The probes used, listed in Table 3, assigned the corresponding sequences to the restriction fragments they hybridized with, although their exact positions remain unknown and, when in the same fragment, the order is arbitrary. Only the markers containing restriction site(s) were precisely located (Fig. 1).

The exact location of the two rrn operons in the O. oeni GM chromosome was determined by hybridization of $r r s$ and $r r l$ probes to the I-CeuI and FseI restriction profiles (Table 3). As in strain PSU-1 (Zé-Zé et al., 1998), these operons have opposite orientations in the genome, $r r n A$ being transcribed clockwise and $r r n B$ anticlockwise (Figs 1 and 2).

Since very few genes of $\mathrm{O}$. oeni have been described, gene-like probes obtained by PCR using degenerate primers (Table 1) and some shotgun clones (Karlyshev et al., 1998) of O. oeni PSU-1 were further analysed by DNA sequencing, aiming to find homologies by database searches, a strategy that is suitable for locating essential genes in organisms with low $\mathrm{G}+\mathrm{C}$ contents when using cloned fragments with $\mathrm{G}+\mathrm{C}$-rich restriction sites (Ladefoged \& Christiansen, 1992). Therefore, the NotI linking clone p-4, plasmid pZAR4.7, as well as small cloned fragments produced by NotI digestion of O. oeni PSU-1 genomic DNA (pZN11, $10 \mathrm{~kb}$; pZN12, $6 \mathrm{~kb}$ ), were sequenced $\sim 700$ nucleotides in each direction using universal vector primers. The insert cloned in pMIR0.5 was sequenced on both strands and its precise size is $557 \mathrm{bp}$. The putative genes found are presented in Table 4.

\section{Improvement of $O$. oeni PSU-1 physical and genetic maps}

The construction of the GM physical map, and the comparative analysis of cross-hybridization results, enabled the mapping of two previously unlocalized SfiI sites in the PSU-1 map (Zé-Zé et al., 1998 and Fig. 2). The use of fragments $\mathrm{S} 10^{\mathrm{PSU}-1}$ and $\mathrm{S} 17^{\mathrm{GM}}$ as probes allowed the assignment of the linkage S7-S10 (clockwise) in the PSU-1 chromosome. As fragment $\mathrm{S} 16^{\mathrm{PSU}-1}$ hybridized to the contiguous GM fragments S11/S12, and $\mathrm{S}_{16} 6^{\mathrm{PSU}-1}$ is located in the region S8-S11 (Zé-Zé et al., 1998), its position must lie between S11 and S14 (see Fig. 2).

All the genetic markers were also located on the O. oeni PSU-1 physical map, as shown in Fig. 2, except for the RAPD 1.2 fragment (hybridization experiment not performed).

\section{Comparison of 0 . oeni GM and PSU-1 genomic maps}

Comparison of the O. oeni GM and PSU-1 physical maps showed that, although there are some polymorphisms in restriction profiles with all enzymes used, in fragment length and number (Table 2, Fig. 2 and ZéZé et al., 1998), there is a high degree of conservation in cleavage sites $(\sim 40 \%)$ and in the order of loci. The fact that NotI-cloned linking sequences of PSU-1 are maintained in the GM physical map and the unambiguous results of cross-hybridization analysis (Table 3 ) support the assumption of global genetic linkage preservation.

The smaller region between the $r r n$ operons, defined by fragments C2 or F1 in both GM and PSU-1, has an overall conservation of restriction sites, whereas the other region, defined by fragment $\mathrm{C} 1$, shows more variation. In terms of size, the C2/F1 region is $41 \mathrm{~kb}$ longer in strain GM. As the size difference between the O. oeni GM (1932 kb) and PSU-1 (1857 kb) chromosomes is $75 \mathrm{~kb}$, a similar level of insertion/deletion events can be expected in both genomic regions.

Putting together the cross-hybridization results, relative dimension of homologous fragments and alignment of GM and PSU-1 physical maps, eight insertion events (in N1, N4, N7, N8, N10, S2, S3 and S16) and a deletion (in S4) were deduced in strain GM. For instance, the insertion of a $19 \mathrm{~kb}$ sequence in $\mathrm{N} 4$ was determined by cross-hybridization of $\mathrm{N}^{\mathrm{PSU}-1}$ and $\mathrm{N} 4^{\mathrm{GM}}$ fragments. As $\mathrm{N} 4^{\mathrm{GM}}(154 \mathrm{~kb})$ fragment only hybridized with $\mathrm{N} 4^{\mathrm{PSU}-1}$ $(135 \mathrm{~kb})$, that region is expected either to contain a duplication or a sequence absent in PSU-1. Although the deletion event in S4 and the insertion in $\mathrm{N} 1$ have the same size $(29 \mathrm{~kb})$, there is no indication of an unequal crossing-over event involving the flanked region taking into account the maintenance of loci order relative to PSU-1. The conservation of several restriction fragments between strains GM and PSU-1 through the whole genome (e.g. N5 and N5, F7 and F8, S6 and S7, S9 and $\mathrm{S} 10, \mathrm{~N} 6$ and N6) is also indicative of the absence of major recombination events, leaving point mutations and localized duplications or transpositions (involving regions smaller than the resolution of the presented map) as the most probable explanation for the observed restriction polymorphisms.

In terms of physical maps, and except for the presence of an extra SfII site in the PSU-1 chromosome, the region defined by $r r n B-\mathrm{N} 5-\mathrm{N} 6$ seems to be largely conserved. Nevertheless, minor differences were detected in the genetic maps, namely the presence of an extra IS1165 
Table 4. Orthologous genes found after sequencing selected plasmid inserts and PCR fragments

\begin{tabular}{|c|c|c|c|c|c|c|c|}
\hline Name* & $\begin{array}{l}\text { Size } \\
(\mathbf{k b}) \dagger\end{array}$ & $\begin{array}{l}\text { Sequence } \\
\text { length } \\
\text { (bp) }\end{array}$ & Homology & $\begin{array}{l}\text { EMBL/SWISS- } \\
\text { PROT } \\
\text { accession no. }\end{array}$ & Gene product & $\begin{array}{c}\text { Percentage } \\
\text { identity (aa } \\
\text { overlap) } \neq\end{array}$ & $\begin{array}{c}\mathrm{G}+\mathrm{C} \\
\text { content } \\
(\mathrm{mol} \%)\end{array}$ \\
\hline pZAR 4.7/T3 & $4 \cdot 7$ & 880 & $\operatorname{araA}$ (B. subtilis) & emb|CAA61585 & $\mathrm{L}$-Arabinose isomerase & $51(291)$ & $37 \cdot 9$ \\
\hline \multirow[t]{2}{*}{$\mathrm{pZAR} 4.7 / \mathrm{T} 7$} & $4 \cdot 7$ & 993 & celR (B. subtilis) & sp|P46321 & $\begin{array}{l}\text { Putative Cel operon } \\
\text { regulator }\end{array}$ & $23(154)$ & $35 \cdot 4$ \\
\hline & & & bglG (B. subtilis) & emb|CAB13057 & $\begin{array}{l}\text { Transcriptional } \\
\text { antiterminator }\end{array}$ & $25(155)$ & \\
\hline gyrB/UP-1 & $1 \cdot 4$ & 222 & $\begin{array}{c}\text { gyrB (Streptococcus } \\
\text { pneumoniae) }\end{array}$ & emb|CAA91553 & DNA gyrase subunit B & $50(54)$ & $41 \cdot 4$ \\
\hline gyrB/UP-2R & $1 \cdot 4$ & 372 & gyrB (S. pneumoniae) & $\mathrm{sp} \mid \mathrm{P} 48373$ & DNA gyrase subunit B & $73(111)$ & $44 \cdot 1$ \\
\hline \multirow[t]{2}{*}{$\begin{array}{l}\text { pMIR0.5/ } \\
\text { T3 and T7 }\end{array}$} & 0.557 & 557 & $\begin{array}{l}\text { ulf- } 250 \text { (Rattus } \\
\text { norvegicus) }\end{array}$ & gi|3978495 & ULF-250 protein & $70(100)$ & $35 \cdot 9$ \\
\hline & & & (B. subtilis) & sp|P50743 & GTP-binding protein & $62(93)$ & \\
\hline $\mathrm{pZN} 11 / \mathrm{T} 3$ & 10 & 566 & $\operatorname{ded} A$ (E. coli) & sp|P09548 & Unknown & $43(89)$ & $38 \cdot 3$ \\
\hline $\mathrm{pZN} 11 / \mathrm{T} 7$ & 10 & 771 & efp (B. subtilis) & $\mathrm{sp} \mid \mathrm{P} 49778$ & $\begin{array}{l}\text { Elongation factor } \mathrm{P} \\
(\text { EF-P) }\end{array}$ & $58(89)$ & $41 \cdot 5$ \\
\hline $\mathrm{pZN12/T3}$ & 6 & 646 & $\operatorname{tgt}$ (B. subtilis) & sp|O32053 & $\begin{array}{l}\text { Queuine tRNA- } \\
\text { ribosyltransferase }\end{array}$ & $56(193)$ & $38 \cdot 9$ \\
\hline $\mathrm{pZN12/T7}$ & 6 & 702 & $\begin{array}{l}\text { clpB (Mycoplasma } \\
\text { pneumoniae) }\end{array}$ & $\mathrm{sp} \mid \mathrm{P} 75247$ & $\begin{array}{l}\text { CLPB ATP-binding } \\
\text { protein }\end{array}$ & $58(29)$ & $45 \cdot 3$ \\
\hline \multirow[t]{3}{*}{$\begin{array}{l}\mathrm{p}-4 / \mathrm{SP} 6 \\
\text { and T7 }\end{array}$} & 14 & 1335 & $\begin{array}{l}\text { lytS (Staphylococcus } \\
\text { aureus) }\end{array}$ & gi|862312 & Autolysis control & $53(308)$ & $39 \cdot 5$ \\
\hline & & & lytR (B. subtilis) & emb|CAA99611.1 & $\begin{array}{l}\text { Autolysin response } \\
\text { regulator }\end{array}$ & 50 (118) & \\
\hline & & & lytR (S. aureus) & gi|1854577 & & $46(128)$ & \\
\hline
\end{tabular}

* Plasmid and primer(s) used for sequencing reactions.

† Size of the cloned insert or PCR fragment.

$\ddagger$ Percentages of aa identity (and overlap) between $O$. oeni predicted protein sequences and the similar protein sequences of other organisms.

sequence in strain PSU-1, and the different location of $\sec A$-like gene in the two chromosomes.

Concerning the restriction sites, an uneven distribution can be observed both for specific enzymes and the overall $\mathrm{G}+\mathrm{C}$-rich sequences. In spite of the identical $\mathrm{G}+\mathrm{C}$ content of their recognition sequences, FseI and Sfil cutting sites predominate in the large fragment defined by the two rrn operons (C1), whereas Not I sites are more frequent in the smaller region $(\mathrm{C} 2)$, both for the GM and PSU-1 genomes. Taking into account the $\mathrm{G}+\mathrm{C}$ content of the restriction sites, and normalizing their distribution according to the size difference of fragments $\mathrm{C} 1$ and $\mathrm{C} 2$, there is no doubt that GC-rich sequences seem to prevail in fragment C1 for strain GM and in fragment C2 for strain PSU-1. Nevertheless, the general agreement in the order of the genetic markers does not support the hypothesis of differential gene spreading in both genomes.

\section{DISCUSSION}

The physical map of O. oeni GM was constructed by a top-down approach (Cole \& Saint-Girons, 1994) using the rare-cutting enzymes AscI, I-CeuI, FseI, NotI and
Sfil, and the chromosome size was estimated as $1932 \mathrm{~kb}$. The map has an average resolution of $46 \mathrm{~kb}$ with the majority of map intervals $(83.3 \%)$ smaller than $100 \mathrm{~kb}$ and, therefore, is in the acceptable range for genetic mapping (Cole \& Saint Girons, 1994). The crosshybridization experiments were invaluable for the GM map construction. The success of this approach and the previous knowledge of the PSU-1 physical map (Zé-Zé et al., 1998), not only made GM mapping relatively easy but also enabled the completion of Sfil mapping in PSU-1.

Hybridization experiments allowed the localization of 26 genetic markers in both maps, including 14 new $O$. oeni putative genes: (i) four PCR products - ccpA-like, hexB, rpoC, secA-like; (ii) $10 \mathrm{ORF}$ identified by database searches of DNA sequences - araA, celR-like, $c l p B$, dedA-like, efp, gcg, gyrB, lytS, lytR and tgt. The known $O$. oeni genes related to the oenological properties of this species, mleA (Labarre et al., 1996) and alsS/alsD (Garmyn et al., 1996), as well as genes essential for replication and transcription (gyrB, rpoC), or involved in mismatch repair (hexB) and NotI linking clones were also mapped. The heterologous probes for 
citP and recA also enabled the localization of the putative orthologous sequences in O. oeni.

The precise location and opposite transcription direction of the two rrn operons (Zavaleta et al., 1996) was determined by Southern hybridization with $r r s$ and $r r l$ homologous probes, taking advantage of the fact that the sequence of these genes is cleaved by FseI and I-CeuI, respectively. The origin and terminus of replication of the $\mathrm{O}$. oeni chromosome remains unknown. However, considering that in most known eubacteria oriC is located near gyrB and $r p o C$, and that the transcription of $r r n$ operons usually occurs in the opposite direction to oriC (Cole \& Saint Girons, 1994), the suggestion of its location in fragment $\mathrm{C} 1$, as proposed by Zé-Zé et al. (1998), is reinforced.

In a study involving $30 \mathrm{O}$. oeni strains, Tenreiro et al. (1994), chose strains GM and PSU-1 as representatives of two divergent genomic groups. The comparative analysis of the genetic maps of these strains presented here (Fig. 2), showed global similarity, in spite of the restriction fragment polymorphisms $(62.5 \%$ of the fragments produced by the five enzymes have different sizes). Although we can speculate that some of the differences in the locations of NotI and SfiI restriction sites in the vicinity of $\mathrm{rrnB}$ operon (Figs 1 and 2) could be due to the IS1165 element, the cause for the majority of the variation remains unknown. As strain GM has no lysogenic derivatives and considering that the chromosomal regions corresponding to both attachment sites in PSU-1 genome (attB1, S8 and attB2, S11; Zé-Zé et al., 1998) presents no considerable difference in the two strains, the in and out movement of bacteriophage DNA cannot explain the overall diversity. As, except for secAlike and IS1165, the order of genetic markers is identical in the two O. oeni chromosomes and the small differences observed are apparently due to insertion/ deletion events that do not affect the global genomic similarity, other differences on the restriction maps probably result from point mutations.

The extensive degree of conservation of the order of loci presented here supports the previously suggested homogeneous nature of O. oeni (Morse et al., 1996; Zavaleta et al., 1996, 1997). As suggested by St. Jean \& Charlebois (1996), there is no objective measure to determine the degree of similarity between genomes and the maps can be preserved despite the potential for rearrangement. Nevertheless, the value of genomic maps per se, both at specific and subspecific levels, can only be ascertained by comparisons involving strains from different taxonomic ranks, in order to assess taxonomic divergence and homogeneity.

\section{ACKNOWLEDGEMENTS}

We express our gratitude to M. A. Santos (Centro de Genética e Biologia Molecular) for providing primers to amplify some DNA probes. L.Z. was the recipient of a research grant from PRAXIS XXI (BD/4541/94).

\section{REFERENCES}

Altschul, S. F., Madden, T. L., Schaffer, A. A., Zhang, Z., Miller, W. \& Lipman, D. J. (1997). Gapped BLAST and PSI-BLAST: a new generation of protein database search programs. Nucleic Acids Res 25, 3389-3402.

Brito, L. (1996). Molecular analysis in Leuconsotoc oenos. PhD thesis, Technical University of Lisbon.

Cole, S. T. \& Saint Girons, I. (1994). Bacterial genomics. FEMS Microbiol Rev 14, 139-160.

Dicks, L. M. T., Vuuren, H. J. J. \& Dellaglio, F. (1990). Taxonomy of Leuconostoc species, particularly Leuconostoc oenos, as revealed by numerical analysis of total soluble cell protein patterns, DNA base compositions and DNA-DNA hybridizations. Int J Syst Bacteriol 40, 83-91.

Dicks, L. M. T., Dellaglio, F. \& Collins, M. D. (1995). Proposal to reclassify Leuconostoc oenos as Oenococcus oeni [corrig.] gen. nov., comb. nov. Int J Syst Bacteriol 45, 395-397.

Duwat, P., Ehrlich, S. D. \& Gruss, A. (1992). A general method for cloning recA genes of gram-positive bacteria by polymerase chain reaction. J Bacteriol 174, 5171-5175.

Duwat, P., Cochu, A., Erlich, S. D. \& Gruss, A. (1997). Characterization of Lactococcus lactis UV-sensitive mutants obtained by ISS1 transposition. J Bacteriol 17, 4473-4479.

Garmyn, D., Monnet, C., Martineau, B., Guzzo, J., Cavin, J.-F. \& Diviès, C. (1996). Cloning and sequencing of the gene encoding $\alpha$ acetolactate decarboxylase from Leuconostoc oenos. FEMS Microbiol Lett 145, 445-450.

Garvie, E. (1986). Genus Leuconostoc. In Bergey's Manual of Systematic Bacteriology, vol. 2, pp. 1071-1075. Edited by P. H. A. Sneath, N. S. Mair, M. E. Sharpe \& J. G. Holt. Baltimore, MD: Williams \& Wilkins.

Heath, J. D., Perkins, J. D., Sharma, B. \& Weinstock, G. M. (1992). NotI cleavage map of Escherichia coli K12 strain MG1655. J Bacteriol 174, 5171-5175.

Johansen, E. \& Kibenich, A. (1992). Isolation and characterization of IS1165, an insertion sequence of Leuconostoc mesenteroides subsp. cremoris and other lactic acid bacteria. Plasmid 27, 200-206.

Karlyshev, A. V., Henderson, J., Ketley, J. M. \& Wren, B. W. (1998). An improved physical and genetic map of Campylobacter jejuni NCTC 11168 (UA580). Microbiology 144, 503-508.

Labarre, C., Diviès, C. \& Guzzo, J. (1996). Genetic organization of the mle locus and identification of mleR-like gene from Leuconostoc oenos. Appl Environ Microbiol 62, 4493-4498.

Ladefoged, S. A. \& Christiansen, G. (1992). Physical and genetic mapping of the genomes of five Mycoplasma hominis strains by pulsed-field gel electrophoresis. J Bacteriol 174, 2199-2207.

Liu, S.-L., Hessel, A. \& Sanderson, K. E. (1993). Genomic mapping with I-CeuI, an intron-encoded endonuclease specific for genes for ribosomal RNA, in Salmonella spp., Escherichia coli and other bacteria. Proc Natl Acad Sci U S A 90, 6874-6878.

Liu, S.-L., Schryvers, A. B., Sanderson, K. E. \& Johnston, R. N. (1999). Bacterial phylogenetic clusters revealed by genome structure. J Bacteriol 181, 6747-6755.

Marshall, P. \& Lemieux, C. (1992). The I-CeuI endonuclease recognizes a sequence of 19 base pairs and preferentially cleaves the coding strand of the Chlamydomonas moewusii chloroplast large subunit rRNA gene. Nucleic Acids Res 20, 6401-6407.

Martínez-Murcia, A. J., Harland, N. M. \& Collins, M. D. (1993). Phylogenetic analysis of some leuconostocs and related organisms 
as determined from large-subunit rRNA gene sequences: assessment of congruence of small- and large-subunit rRNA derived trees. J Appl Bacteriol 74, 532-541.

Morse, R., Collins, M. D., O'Hanlon, K., Wallbanks, S. \& Richarson, P. T. (1996). Analysis of the $\beta^{\prime}$ subunit of DNA-dependent RNA polymerase does not support the hypothesis inferred from $16 \mathrm{~S}$ rRNA analysis that Oenococcus oeni (formerly Leuconostoc oenos) is a tachytelic (fast-evolving) bacterium. Int J Syst Bacteriol 46, 1004-1009.

Peynaud, E. \& Domercq, S. (1968). Etude de quatre cents souches de conques heterolactiques isolés de vins. Ann Inst Pasteur 19, 159-169.

Philipp, W. J., Nair, S., Guglielmi, G., Lagranderie, M., Gicquel, B. \& Cole, S. T. (1996). Physical mapping of Mycobacterium bovis BCG Pasteur reveals differences from the genome map of Mycobacterium tuberculosis H37Rv and from M. bovis. Microbiology 142, 3135-3145.

St. Jean, A. \& Charlebois, R. L. (1996). Comparative genomic analysis of the Haloferax volcani DS2 and Halobacterium salinarium GRB contig maps reveals extensive rearrangement. J Bacteriol 178, 3860-3868.

Sá-Nogueira, I., Nogueira, T. V., Soares, S. \& de Lencastre, H. (1997). The Bacillus subtilis l-arabinose (ara) operon: nucleotide sequence, genetic organization and expression. Microbiology 143, 957-969.

Sesma, F., Gardiol, D., Holgado, A. P. R. \& de Mendoza, D. (1990). Cloning of the citrate permease gene of Lactococcus lactis subsp. lactis biovar diacetylactis and expression in Escherichia coli. Appl Environ Microbiol 56, 2099-2103.
Tenreiro, R., Santos, R., Brito, L., Paveia, H., Vieira, G. \& Santos, M. A. (1993). Bacteriophages induced by mitomycin $C$ treatment of Leuconostoc oenos strains from Portuguese wines. Lett Appl Microbiol 16, 207-209.

Tenreiro, R., Santos, M. A., Paveia, H. \& Vieira, G. (1994). Interstrain relationships among wine leuconostocs and their divergence from other Leuconostoc species, as revealed by low frequency restriction fragment analysis of genomic DNA. J Appl Bacteriol 77, 271-280.

Yamamoto, S. \& Harayama, S. (1995). PCR amplification and direct sequencing of gyrB genes with universal primers and their application to the detection and taxonomic analysis of Pseudomonas putida strains. Appl Environ Microbiol 61, 1104-1109.

Zavaleta, A. l., Martínez-Murcia, A. J. \& Rodríguez-Valera, F. (1996). 16S-23S rDNA intergenic sequences indicate that Leuconostoc oenos is phylogenetically homogeneous. Microbiology $142,2105-2114$.

Zavaleta, A. I., Martínez-Murcia, A. J. \& Rodríguez-Valera, F. (1997). Intraspecific genetic diversity of Oenococcus oeni as derived from DNA fingerprinting and sequence analysis. Appl Environ Microbiol 63, 1261-1267.

Zé-Zé, L., Tenreiro, R., Brito, L., Santos, M. A. \& Paveia, H. (1998). Physical map of the genome of Oenococcus oeni PSU-1 and localization of genetic markers. Microbiology 144, 1145-1156.

Received 30 May 2000; revised 18 August 2000; accepted 22 August 2000. 